\title{
KUKA KR5 ipari robotkar szingularitásának vizsgálata
}

\author{
Molnár Zsolt \\ Mechatronikai Tanszék \\ Debreceni Egyetem, Müszaki \\ Kar \\ Debrecen, Magyarország \\ zsolt.molnar94@gmail.com
}

\author{
Nwachukwu C. Obinna \\ Mechatronikai Tanszék \\ Debreceni Egyetem, Müszaki \\ Kar \\ Debrecen, Magyarország \\ nwachukwucobinna@gmail.com
}

\author{
Erdei Timotei István \\ Mechatronikai Tanszék \\ Debreceni Egyetem, Müszaki \\ Kar \\ Debrecen, Magyarország \\ timoteierdei@eng.unideb.hu
}

\author{
Dr. habil. Husi Géza \\ Mechatronikai Tanszék \\ Debreceni Egyetem, Müszaki \\ Kar \\ Debrecen, Magyarország \\ husigeza@eng.unideb.hu
}

\begin{abstract}
Absztrakt-A Debreceni Egyetem Müszaki Karának Mechatronikai Tanszékén több, a KUKA KR5 Arc robotot is magába foglaló kutatás zajlik. A robot egy komplex mechatronikai rendszer, amely használata, tanulmányozása és megértése által a hallgatók mélyebb betekintést nyerhetnek a mechatronika tudományának területébe. Ilyen robotokat használnak az iparban is hegesztési feladatok ellátására. Azonban nagy üzembiztonságának ellenére, mint minden komplex rendszernek, az ipari robotnak is megvannak a maga gyenge pontjai, mégpedig a szingularitási pontok. $\mathrm{E}$ cikk keretein belül mérnöki szemszögből került megközelítésre egy, az ipart érintő komplex matematikai probléma.
\end{abstract}

Kulcsszavak- KUKA; szingularitás; inverz kinematika; szabadságfok; Arduino; szimuláció

\section{BEVEZETŐ}

A Debreceni Egyetem Mechatronikai Tanszékének Épületmechatronikai Kutatóközpontjában [1] több, a KUKA KR5 Arc robottal kapcsolatos kutatás is zajlik. Egyik ilyen közülük a robotot egy Kibővített Valóságba (Augmented Reality) integráló rendszer kialakítása [2].

Ezek a robotok nagy megbízhatóságuk mellett szó szerinti gyenge pontokkal is rendelkeznek. Ezeket nevezzük szingularitási pontoknak, ahol a robotkar működés közben vészleállás vagy elöre nem látható viselkedést produkál [3]. Ennek a problémának a visszavezetése a robotkart vezérlő szoftver komplex matematikai hátteréhez vezet. Amit tudni kell a robotkarról, hogy 6 rotációs mozgást végző csuklóponttal rendelkezik, ez adja a 6 szabadságfokát. Ezeket mozgatva köríven történő mozgások megvalósítására alkalmas.

Az iparban lévő komplex feladatok elvégzéséhez azonban lineáris mozgások is elengedhetetlenek. Ennek érdekében a robot derékszögü koordinátarendszer szerint kell tudjon mozogni. Ennek elérése érdekében az úgynevezett inverz kinematikai transzformációkat alkalmazzák [4], amelyik a derékszögü koordináta rendszerben való elmozdulást áttranszformálja a robotkar csuklópontjainak szögelfordulásává. Ezáltal a mechanikailag csak rotációs mozgásokkal ellátott robotkart lineáris mozgásokat is képes megvalósítani, akár egy CNC marógép [5].

A szingularitás kialakulásának oka, hogy az inverz kinematikai transzformáció során a transzformációban résztvevő Jacobi mátrix rangja nem lesz maximális. Ez mechanikailag úgy fogalmazható meg, hogy szabadságfok vesztés történik. Egyik ilyen helyzet például, ha két csuklópont tengelye egy vonalba esik.

Ezekkel a helyzetekkel a mai napig küzdenek, a gyökér okot megszüntetni eddig nem sikerült, viszont mérnöki szemlélettel megközelítve tanulmányozhatjuk a robotkar viselkedését e pozíciókban.

\section{MÉRÉS ÖSSZEÁLLÍTÁSA}

Mivel a szingularitás gyökér oka az inverz kinematika mögött lévő komplex matematikában rejlik és napjainkig ezt közvetlenül nem sikerült megoldani, ezért a hangsúlyt nem ennek a megszüntetésére fektetődött, hanem a robotkar ismert szingularitásaiban való viselkedésének vizsgálatára.

Ennek érdekében egy mérörendszer lett összeállítva, amely több egységből áll. A robotkar végének az egyenes vonalú elmozdulástól való eltérése két féle képen kerül mérésre, közvetlenül a szerszámbefogó megfogónál és párhuzamosan ezzel rögzítésre kerülnek a pontok, amelyeken a robot szingularitás alatt halad át. 


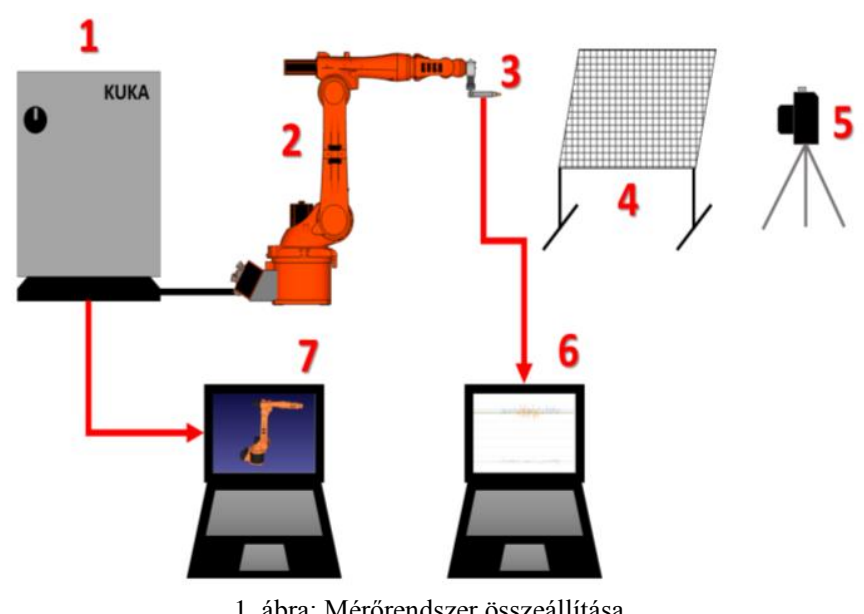

Annak érdekében, hogy a robot ne adjon hibajelzést és ne álljon le, a mozgásokat kézi vezérléssel kellett megvalósítani. Előre programozott mozgások esetén a szingularitási pontban vészleállást eredményez.

A 1. ábrán látható a mérőrendszer összeállítása. Ez a következő elemekből áll:

1. KUKA robothoz tartozó vezérlőszekrény

2. KUKA KR5 Arc robotkar

3. Lézert, gyorsulás és szögsebességméröt tartalmazó méröfej

4. Beosztott vászon

5. Rögzítő fényképezőgép hosszú expozíciós idővel

6. Gyorsulási adatokat rögzítő netbook

7. Koordinátákat rögzítő laptop

$\mathrm{Az}$ 1. ábra 7. jelölt laptopon a robot koordinátáit rögzítő program van futtatva. Itt szükség volt a nagy számítási teljesítményre, mivel egy időben a pontok rögzítését végző szoftver a robotkar 3D modelljét is megjelenítette, ami a valós robotkarnak megfelelően mozgott a virtuális térben. A koordináták lekérdezéséhez a KUKA vezérlőszekrénye és a laptop között egy UTP hálózati kábel segítségével került megvalósításra a kapcsolat. A felhasznált laptop Lenovo ideapad Z710 [6] típusú, amelyik a következő paraméterekkel rendelkezik:

- $\quad$ Processzor: Intel Core i7-4710MQ (4 mag, 8 szál)

- $\quad$ RAM: 8 GB DDR3

- Kijelző: 17,3"méret, 1920 X 1080 pixeles felbontású

- Grafikus gyorsító: Dedikált NVIDIA GT840M, 2 GB grafikus memória

- Háttértár: 1 TB HDD, 5400 RPM

- Tömeg: 2,89 kg

- Akkumulátor kapacitása: $41 \mathrm{Wh}$

- Egyéb: Gigabit Ethernet csatlakozó (KUKA vezérlőszekrényhez való csatlakozáshoz használva)

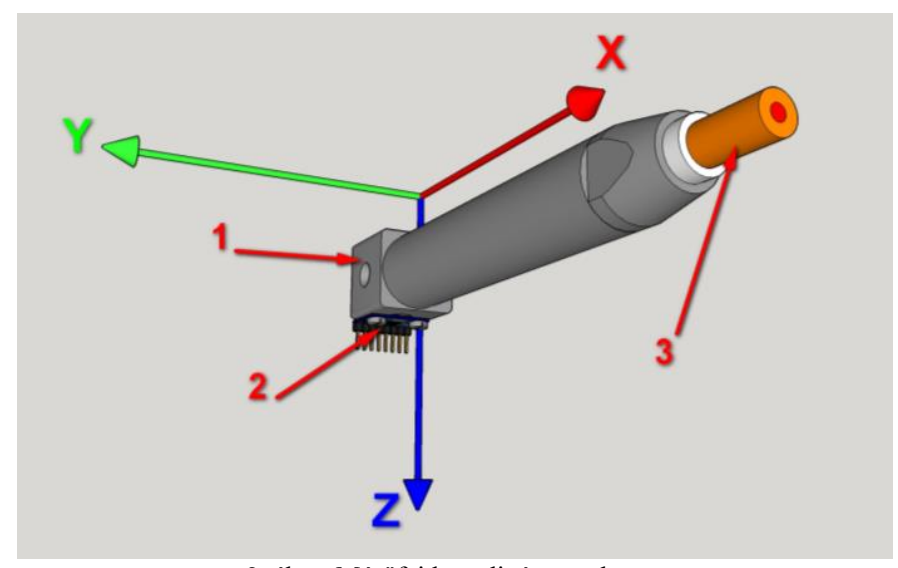

2. ábra: Méröfej koordináta rendszere

A gyorsulás és szögsebességmérő adatait egy netbook (1. ábra, 6.) segítségével kerültek rögzítésre. Az érzékelő egység egy Arduino NANO [7] panelhez került csatlakoztatásra, ami az $\mathrm{I}^{2} \mathrm{C}$ bus-on kommunikáló érzékelő adatait USB porton keresztül kiküldte a netbook számára rögzítésre. A mérőfejben kapott ugyancsak helyet a lézer is, amelyiknek a tápellátása a kis fogyasztása miatt az érzékelő táplálásáról került megvalósításra. A 2. ábrán látható a mérőfej a gyorsulás és szögsebességmérő által meghatározott koordináta rendszerben. Az X, Y, Z koordináták a gyorsulás pozitív irányaiba mutatnak, a szögsebességmérő pedig ezek tengelyek menti elfordulási sebességeket méri. A 2. ábrán látható mérőfej a következő részekből áll:

1. Mérőfej befogását biztosító kialakítás

2. Gyorsulás és szögsebességmérő

3. Lézersugarat létrehozó modul (lézer)

A gyorsulás és szögsebességmérő egy MPU-6050 [8] MEMS [9] technológián alapuló érzékelő. Alkalmas 3 tengely mentén a lineáris gyorsulás mérésére és e 3 tengely mentén történő szögelfordulás sebességének mérésére. Maximális frissítési frekvenciája, amivel képes mérni az értékeket: $40 \mathrm{~Hz}$, beépített 16 bit-es Digitális Analóg átalakítóval rendelkezik.

A lézer tekintetében egy vörös fényt kibocsájtó (650 nm hullámhosszú), $5 \mathrm{~mW}$ teljesítményü modul került kiválasztásra [10]. Ez egyben tartalmazza a lézerfényt létrehozó diódát, lézerfényt párhuzamosító lencsét (pont létrehozása) és a tápfeszültség elöállítását a dióda számára $5 \mathrm{~V}$ bemeneti feszültségből. Ennek az intenzitása ideálisnak bizonyul a mérés előtti tesztek során a mérés elvégzéséhez.

A gyorsulás és szögsebességmérő által mért adatok rögzítéséhez használt netbook (1. ábra, 6.) egy Dell Inspiron Mini 1080 [11], számítási teljesítmény szempontjából a laptophoz képes sokkal kisebb.

A központi elem, amelynek a paraméterei fontosak számunkra, az maga a KUKA KR5 Arc robotkar. Ennek a fizikai és mechanikai tulajdonságai fontosak a mérések elvégzése érdekében. Fő jellemzői [12]: 
- $\quad$ Axisok száma: 6

- Munkaterület térfogata: $8,4 \mathrm{~m}^{3}$

- $\quad$ Pozíció ismétlési pontossága (ISO 9283): $\pm 0,04 \mathrm{~mm}$

- Tömege: megközelítőleg $127 \mathrm{~kg}$

- $\quad$ Felszerelhetőség: talaj, plafon

Ezekből az adatokból megtudtuk, hogy a szingularitás vizsgálatakor $0,04 \mathrm{~mm}$ eltérés nem számít problémának. Továbbá, hogy egy 6 szabadságfokú robotkarról van szó.

Ezen kívül fontos a robot egyes axisainak forgástartományának az ismerete, annak érdekében, hogy a tesztek során tudjuk, milyen határok között lehet mozgatni. A vezérlő ezek megközelítésekor automatikusan vészleállást produkál, azonban az ismeretük által a mérés során figyelve ezekre, az ilyen helyzeteket el lehet kerülni. Ezeket a határokat az alábbi táblázat foglalja össze. Az 1. táblázatban ismertetett értékek a szoftveres korlátokra vonatkoznak, vagyis ezeknek az elérése lehetséges és nem jár a robot károsodásával.

1. táblázat: Axisok mozgástartománya és sebességei [12]

\begin{tabular}{|c|c|c|}
\hline Axisok & $\begin{array}{c}\text { Szoftveresen korlátozott } \\
\text { mozgástartomány }\end{array}$ & $\begin{array}{c}\text { Maximális sebesség } \\
\text { megengedett terhelés } \\
\text { mellett }\end{array}$ \\
\hline 1 & $+/-155^{\circ}$ & $154 \% \mathrm{~s}$ \\
\hline 2 & $+65^{\circ}$ és $-180^{\circ}$ & $154 \%$ \\
\hline 3 & $+158^{\circ}$ és $-15^{\circ}$ & $228 \% \mathrm{~s}$ \\
\hline 4 & $+/-350^{\circ}$ & $343 \%$ \\
\hline 5 & $+/-130^{\circ}$ & $384 \% \mathrm{~s}$ \\
\hline 6 & $+/-350^{\circ}$ & $721 \% \mathrm{~s}$ \\
\hline
\end{tabular}

\section{A LÉZERES MÉRÉSI MÓDSZER}

A következő fő része a mérésnek az úgynevezett fényfestés [13] módszerrel történő pálya kirajzolása. Ennek alapja, hogy egy erre alkalmas fényképezőgépet hosszú expozíciós időre (30 másodperc) állítunk és a fényképezőgépet stabilan tartva a látómezejében egy fényes pontot mozgatunk. Ennek következtében a fényképezőgép az exponálás alatt a fényes pont minden egyes pozícióját rögzíti, így kirajzolva az elmozdulás pályáját.

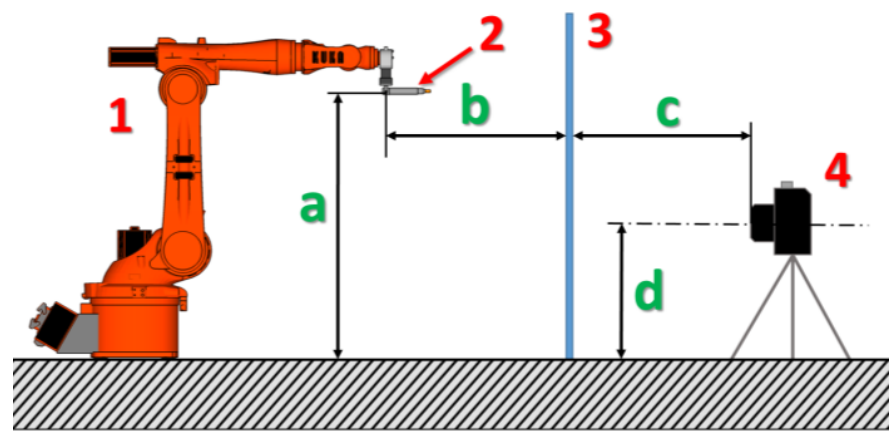

3. ábra: Fényfestéses mérés összeállítása

A 3. ábrán látható a fényfestéses méréshez szükséges eszközöknek az elrendezése. Itt jelölve lettek a mérésnél alkalmazott távolságok a megismételhetőség érdekében. Ezeket az értékeket a 2. táblázat tartalmazza. Felülnézetből a robotkaron található mérőfej (3. ábra, 2.) tengelye egy vonalba esik a fényképezőgép lencséjének tengelyével. A fényképezőgép (3. ábra, 4.) és a robotkar (3. ábra, 1.) távolsága a beosztott vászonhoz (3. ábra, 3.) viszonyítva kerültek megadásra.

A mérőfej referenciapontjául a rászerelt gyorsulás és szögsebességmérőn található érzékelést végző integrált áramkör középpontja lett választva, mivel itt keresztezik az érzékelő tengelyei egymást. Erre a pontra történt a szerszámbemérés is.

2. táblázat: Jelölt méretek értékei

\begin{tabular}{|c|c|c|c|c|}
\hline Jelölés & a & b & c & d \\
\hline Méret $[\mathbf{m m}]$ & 1015 & 1943 & 1594 & 841 \\
\hline
\end{tabular}

A robotkar a mérések kezdetekor minden esetben alap HOME pozíciójából került indításra. E pozícióban az egyes axisok a 3. táblázatban ismertetett szögekben állnak.

3. táblázat: Axisok állása HOME pozícióban

\begin{tabular}{|c|c|c|c|c|c|c|}
\hline Axis & 1 & 2 & 3 & 4 & 5 & 6 \\
\hline Szög $\left[^{\circ}\right]^{\circ}$ & $0^{\circ}$ & $-90^{\circ}$ & $90^{\circ}$ & $0^{\circ}$ & $0^{\circ}$ & $0^{\circ}$ \\
\hline
\end{tabular}

Ezeket az értékeket ellenőrzésként használjuk fel, hogy minden egyes szingularitási mérés elkezdése előtt ellenőrizzük, hogy a robot kezdeti pozícióból indul-e.

A beosztott vászonként egy papírra nyomtatott $1 \mathrm{~cm}$-es beosztású rács szolgált. Ez kifeszített állapotban került rögzítésre a robotkar és a fényképezőgép közé. A mérések megkezdése elött a robotot szingularitási állapoton kívül mozgatva, a vászon a robot vízszintes pozíciójához lett igazítva majd egy tesztméréssel ellenőrizve a mérés összeállításának helyessége.

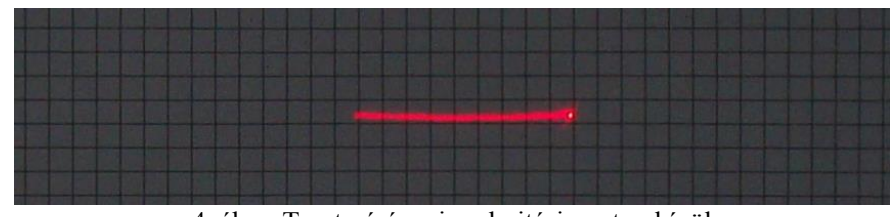

4. ábra: Tesztmérés szingularitási ponton kívü

A 4. ábrán látható, hogy a robot $100 \mathrm{~mm}$-t volt elmozgatva és egyenes vonalban haladt, ahogy azt elvárhattuk szingularitási ponton kívül. 


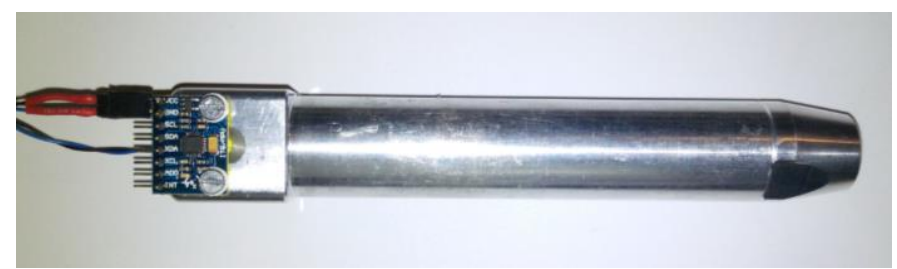

5. ábra: Összeszerelt mérőfej

Az 5. ábrán az összeszerelt mérőfej látható. A 3D modellel ellentétben, itt a lézermodul nem látszik, mivel az beépítésre került a fej vázába a jobb mechanikai stabilitás elérése érdekében. A bal oldali részén a gyorsulás és szögsebességmérő szenzor látható és a lézermodul tápvezetékének a csatlakoztatása.

\section{SZINGULARITÁSOK VIZSGÁLATA}

A KUKA kinematikai rendszerében 3 különböző szingularitási típus között van különbség téve [3]. Ezek a fejfölötti szingularitások (overhead singularity), kinyújtott pozícióban jelentkező szingularitás és a csukló szingularitása. Ezek közül a mérések során a csukló szingularitása két esetben és a fejfölötti szingularitás egy esetben került vizsgálatra.

A három vizsgált szingularitási helyzet közül a fejfölötti szingularitás a kiemelendő. A mérések során ugyanis ebben az esetben a robot kézi vezérléssel sem volt használható. 30\%-os sebességtartomány alatt a robot a szingularitási ponton nem tudott túllendülni. E sebesség alatt áthaladni a ponton a robot „kicsavarodásával” járt, ami leálláshoz vezetett. Ezt az állapotot a 6. ábra szemlélteti.

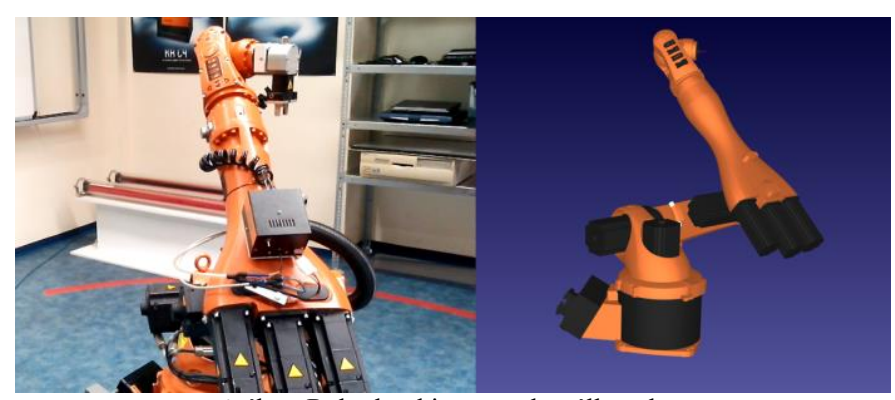

6. ábra: Robotkar kicsavarodott állapotban

A szingularitáson való áthaladás során a robotkar pozíciói rögzítésre kerültek. Ezeket utólagosan elemezve, megállapításra kerültek az $\mathrm{Y}$ és $\mathrm{Z}$ tengely eltérései az alapállapothoz képest. az $Y$ és $Z$ értékei azért kellene állandónak lenniük, mivel a robot mozgatása az $\mathrm{X}$ tengely mentén történt. Számszerüen az eltérések: Y tengely mentén: $3,164 \mathrm{~mm}, \mathrm{Z}$ tengely mentén $24,459 \mathrm{~mm}$. A HOME pozícióhoz képest a nevezetes pontokban a koordináta értékeket a 4. táblázat foglalja össze. Jelölve vannak azon értékeke, amelyek között a legnagyobb eltérés van.

4. táblázat: Koordináta eltérések

\begin{tabular}{|c|c|c|c|}
\hline & $\mathbf{X}[\mathbf{m m}]$ & $\mathbf{Y}[\mathbf{m m}]$ & $\mathbf{Z}[\mathbf{m m}]$ \\
\hline HOME pozíció & 915,000 & 0,000 & 1120,000 \\
\hline Kezdőpont & 150,000 & $-0,031$ & 1117,967 \\
\hline Végpont & 52,986 & 0,448 & 1116,225 \\
\hline Távoli kitérés & 112,301 & 3,133 & 1095,541 \\
\hline
\end{tabular}

\section{V. ÖSSZEGZÉS}

Összefoglalásként elmondható, hogy sikeresen létre lett hozva egy komplex mérörendszer a Robottechnológiai laboratóriumban. A mérőrendszer virtuális térben történő szimulációt foglal magába a valós robot mozgásai alapján. A robotkart mozgásának gyorsulásait, szögsebességeit képes mérni és rögzíteni, valamint a fényfestés fényképezési technika alkalmazásával megjelenítésre került a szingularitáskor való elmozdulások.

\section{KÖSZÖNETNYILVÁNÍTÁS}

A publikáció elkészítését az EFOP-3.6.1-16-2016-00022 számú projekt támogatta. A projekt az Európai Unió támogatásával, az Európai Szociális Alap társfinanszírozásával valósult meg.

\section{HIVATKOZÁSOK}

[1] G. Husi, P. T. Szemes, E. Dávid, T. I. Erdei, „Building Mechatronics Research Centre as energy aware Intelligent Space," in Industrial Electronics Society - IECON 2013 - 39th Annual Conference of the IEEE, 01/2013.

[2] Timotei István Erdei, Zsolt Molnár, Nwachukwu C. Obinna, Géza Husi, „Cyber physical systems in mechatronic research centre," MATEC Web of Conferences 126, 01006, Annual Session of Scientific Papers IMT ORADEA 2017, DOI: 10.1051/matecconf/201712601006, 2017.

[3] Géza Husi, „Position Singularities and Ambiguities of the KUKA KR5 Robot," INTERNATIONAL JOURNAL of ENGINEERING TECHNOLOGIES, Vol. 1, No. 1., 2015.

[4] Richard P. Paul, Robot Manipulators: Mathematics, Programming, and Control, The MIT Press, ISBN: 978-0-262-16082-7, 1981.

[5] Molnár Zsolt, Erdei Timotei István, Almusawi Husam, Husi Géza, „SAJÁT CNC PROTOTÍPUS RENDSZER MINT IOT ESZKÖZ,” in Müszaki tudományos közlemények 7, Kolozsvár, Erdélyi Múzeum Egyesület (EME), ISBN: 978-963-449-018-0 , 2017, pp. 295-298.

[6] Lenovo, „Lenovo Z710,” [Online]. Available: https://www3.lenovo.com/us/en/laptops/lenovo/z-series/z710/. [Hozzáférés dátuma: 0110 2017].

[7] Arduino, „Arduino NANO,” [Online]. Available: https://store.arduino.cc/usa/arduino-nano. [Hozzáférés dátuma: 0509 2017].

[8] InvenSense, „MPU-6000 and MPU-6050 Product Specification,” [Online]. Available: https://www.invensense.com/wpcontent/uploads/2015/02/MPU-6000-Datasheet1.pdf. [Hozzáférés dátuma: 0209 2017].

[9] Nwachukwu C. Obinna, Syeda Adila Afghan, Timotei Istvan Erdei, Zsolt Molnar, Dr. Peter Szemes, Dr. Geza Husi, „LabVIEW Motion Planning and Tracking of an Aerial Robotic System: Dynamic Simulation of the Robot's Embedded Vibratory MEMS Gyroscope," https://www.researchgate.net, DOI: 10.13140/RG.2.2.17163.18720, 2017. 
[10] HESTORE, „LASM-987,” [Online]. Available: https://www.hestore.hu/prod_10035542.html. [Hozzáférés dátuma: 20 11 2017].

[11] Dell, „Dell Inspiron Mini 1018,” [Online]. Available: http://www.dell.com/en-us/shop/cty/pdp/spd/inspiron-mini1018. [Hozzáférés dátuma: 2010 2017].

[12] KUKA Roboter Group, „KR 5 Arc - Specification,” [Online]. Available:

https://www.google.hu/url?sa=t\&rct=j\&q=\&esrc=s\&source=web\&cd= $1 \&$ ved $=0$ ahUKEwiSraO5i-

DXAhXHFOwKHcr0AkkQFggnMAA\&url=https\%3A\%2F\%2Fwww. kuka.com\%2F-\%2Fmedia\%2Fkuka-
downloads\%2Fimported\%2F48ec812b1b2947898ac2598aff70abc0\%2 Fspez_kr_5_arc_en.pdf\&usg=AOvVaw31SKs98V. [Hozzáférés dátuma: 1010 2017].

[13] Digital Photography School, „Light Painting,” [Online]. Available: https://digital-photography-school.com/light-painting-part-one-thephotography/. [Hozzáférés dátuma: 3009 2017]. 